\title{
ANTIVIRAL ACTIVITY OF THE GREEN MARINE ALGA UIva fasciata ON THE REPLICATION OF HUMAN METAPNEUMOVIRUS
}

Gabriella da Silva MENDES(1), Angélica Ribeiro SOARES(2), Fernanda Otaviano MARTINS(1), Maria Carolina Maciel de ALBUQUERQUE(3), Sonia Soares COSTA(4), Yocie YONESHIGUE-VALENTIN(5), Lísia Mônica de Souza GESTINARI(2), Norma SANTOS(3) \& Maria Teresa Villela ROMANOS(1)

\begin{abstract}
SUMMARY
We evaluated the antiviral activity of the marine alga, Ulva fasciata, collected from Rasa beach and Forno beach, Búzios, Rio de Janeiro, Brazil on the replication of human metapneumovirus (HMPV). The algae extracts were prepared using three different methodologies to compare the activity of different groups of chemical composites obtained through these different methodologies. Four out of the six extracts inhibited nearly $100 \%$ of viral replication. The results demonstrated that the majority of the extracts (five out of six) possess virucidal activity and therefore have the ability to interact with the extracellular viral particles and prevent the infection. On the other hand, only two extracts (from Forno beach, obtained by maceration and maceration of the decoction) were able to interact with cell receptors, hindering the viral entry. Finally, only the extract of algae collected at Forno beach, obtained by maceration presented intracellular activity. To our knowledge, this is a pioneer study on antiviral activity of marine algae against HMPV. It is also the first on antiviral activity against HMPV ever done in Brazil. The study also shows the effect of different environment factors and different chemical procedures used to obtain the extract on its biological properties.
\end{abstract}

KEYWORDS: Antiviral; Human metapneumovirus; Marine alga; Respiratory infection.

\section{INTRODUCTION}

Acute respiratory infections (ARIs) are the major cause of childhood morbidity and mortality worldwide. Viruses account for the majority of ARIs in young children and most infections are attributed to respiratory syncytial virus (RSV), parainfluenza virus (PIVs), influenza virus (FluV), rhinovirus $(\mathrm{RV})$ and adenovirus $(\mathrm{AdV})^{7,25,28,49}$. Over the past few years newly described viruses were associated to respiratory infection such as human metapneumovirus (HMPV), the emerging human coronaviruses ( $\mathrm{HCoV})$, human bocavirus (HBoV), and the new human papillomaviruses KIPyV and WUPyV ${ }^{20,43}$.

Human metapneumovirus is a species in the genus Metapneumovirus, family Paramyxoviridae, and was isolated in 2001 by VAN DEN HOOGEN et al. in previously virus-negative nasopharyngeal aspirates from children with respiratory tract infections ${ }^{46}$. Although HMPV infections have been diagnosed in all age groups, this virus has its greatest effect in children ${ }^{12}$. Several studies demonstrated that HMPV accounts for a major proportion of hospitalizations for lower respiratory tract infections in infants and young children ${ }^{30,47,50}$. The most frequent diagnoses in hospitalized children are bronchiolitis and pneumonia, but occasionally HMPV may also cause severe illnesses that require treatment at intensive care units ${ }^{41}$. The burden of HMPV infection in
Brazil has already been demonstrated ${ }^{3,5,8,31,35}$. No vaccine or antiviral therapy is currently available for prevention or treatment of HMPV infection. However, it has been demonstrated that the antiviral activity of ribavirin against HMPV is equivalent to that observed with $\mathrm{RSV}^{53}$. Also, the NMSO3 compound, a sulfated sialyl lipid, has been shown to have antiviral activity against HMPV ${ }^{54}$.

Several natural products can inhibit viruses. Marine natural products contain an abundance of biologically active substances with novel chemical structures and favorable pharmacological activities ${ }^{26,27}$. Marine organisms are also a promising source of antiviral compounds ${ }^{13,26,27}$. Several investigators described the inhibitory effects of algal extracts and their constituents on the replication of some respiratory viruses ${ }^{10,11,18,19,34,42}$. Nevertheless, no reports of antiviral activity of marine algae against HMPV has been published, so far. The aim of this study was to evaluate the antiviral activity of a marine alga (Ulva fasciata) on the replication of HMPV.

\section{MATERIALS AND METHODS}

1. Algal extracts: The alga Ulva fasciata was collected in two distinct areas of the Southeastern Brazilian coast in March 2006: Forno Beach and Rasa Beach, both located at the city of Búzios, Rio de Janeiro

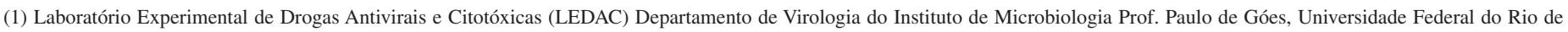
Janeiro (UFRJ), CCS, Bloco I, Rio de Janeiro, RJ, Brasil.

(2) Grupo de Produtos Naturais de Organismos Aquáticos (GPNOA), Núcleo em Ecologia e Desenvolvimento Sócio-Ambiental de Macaé (NUPEM), UFRJ

(3) Laboratório de Viroses Respiratórias, Entéricas e Oculares Departamento de Virologia do Instituto de Microbiologia Prof. Paulo de Góes/UFRJ.

(4) Núcleo de Pesquisa de Produtos Naturais/UFRJ.

(5) Departamento de Botânica, Instituto de Biologia/UFRJ.

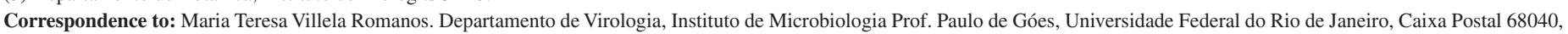
21941-590 Rio de Janeiro, RJ, Brasil. Tel.: 55.21.2260-9311, FAX: 55.21.2560-8344. E-mail: teresa.romanos@micro.ufrj.br 


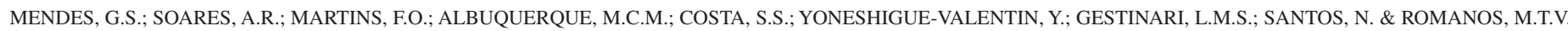
- Antiviral activity of the green marine alga Ulva fasciata on the replication of human metapneumovirus. Rev. Inst. Med. Trop. São Paulo, 52(1): 3-10, 2010.

State. The algal material was washed in seawater to eliminate associated organisms and then air-dried at ambient temperature. Voucher specimens (Forno: RFA33611 and Rasa: 33610) were deposited at the Herbarium of the Rio de Janeiro Federal University, Brazil.

The material was separated in equal quantity and extracts were obtained using three different processes: (i) maceration with dichloromethane: methanol (1:1); (ii) decoction with boiling water and (iii) maceration of the decoction with dichloromethane: methanol (1:1) (Table 1). The solvents were evaporated and all the crude extracts were lyophilized. All the extracts obtained were analyzed by Thin Layer Chromatography (TLC). Thin Layer Chromatography (TLC) was performed with Kieselgel $60 \mathrm{~F}_{254}$ aluminum support plates (Merck). The decoction and the maceration of the decoction extracts were analyzed by ${ }^{1} \mathrm{H}$ NMR and ${ }^{13} \mathrm{C}$ NMR spectroscopy. ${ }^{1} \mathrm{H}(200 \mathrm{MHz})$ and ${ }^{13} \mathrm{C}$ NMR $(50 \mathrm{MHz})$ spectra were recorded using Bruker Advance spectrometer. Chemical shifts are given in $\delta(\mathrm{ppm})$ scale using TMS as internal standard. All the analyses were measured in $\mathrm{CDCl}_{3}$. The decoction extracts were analyzed by infrared (IR) spectroscopy. For IR spectrometry a FT-IR Perkin-Elmer spectrum one spectrometers was used.

Table 1

Algal extracts and cytotoxicity

\begin{tabular}{|c|c|c|c|c|}
\hline Alga & Location & $\begin{array}{l}\text { Extraction } \\
\text { method }\end{array}$ & $\begin{array}{c}\text { Concentration } \\
\text { used } \\
(\mu \mathrm{g} / \mathrm{mL})\end{array}$ & $\begin{array}{l}\text { Viable } \\
\text { cells } \\
(\%)\end{array}$ \\
\hline \multirow[t]{6}{*}{ Ulva fasciata } & Rasa beach & Maceration & 25 & 85.6 \\
\hline & & Decoction & 100 & 85.5 \\
\hline & & $\begin{array}{l}\text { Maceration of } \\
\text { the decoction }\end{array}$ & 12.5 & 83.7 \\
\hline & Forno beach & Maceration & 25 & 83.6 \\
\hline & & Decoction & 100 & 80.1 \\
\hline & & $\begin{array}{l}\text { Maceration of } \\
\text { the decoction }\end{array}$ & 25 & 85.1 \\
\hline
\end{tabular}

The extracts were solubilized in dimethyl sulphoxide (DMSO) to a final concentration of $1 \%$ and diluted in water to a concentration of 400 $\mu \mathrm{g} / \mathrm{mL}$, sterilized by filtration using Millipore membrane $(0.22 \mu \mathrm{m})$ and frozen at $-20{ }^{\circ} \mathrm{C}$ until use.

2. Cell culture: Vero cells were grown in Eagle's minimum essential medium (MEM-Eagle) supplemented with $2 \mathrm{mM} \mathrm{L}$-glutamine, $50 \mu \mathrm{g} / \mathrm{mL}$ garamicin, $2.5 \mu \mathrm{g} / \mathrm{mL}$ fungizon, sodium bicarbonate at $0.25 \%$, and $10 \%$ of heat-inactivated fetal bovine serum (FBS) and maintained at $37^{\circ} \mathrm{C}$ in an atmosphere of $5 \% \mathrm{CO}_{2}$.

3. Virus: A sample of HMPV NL/1/00 was kindly provided by ViroNovative BV, Erasmus University Rotterdam (The Netherlands). Because the viral replication in vitro is dependent of trypsin, this enzyme was added to the culture medium for a final concentration of $1 \mu \mathrm{g} / \mathrm{mL}$ for the antiviral experiments.

4. Determination of cytotoxicity: The cytotoxicity assay was performed by incubating Vero cell monolayers cultivated in 96-well microplates with two-fold serial dilutions of the extracts, in triplicate, for seven days at $34{ }^{\circ} \mathrm{C}$. The cellular viability was further evaluated by the neutral red dye-uptake method $^{29}$.

5. Antiviral assay: Vero cell monolayers cultivated in 48 wellmicroplates were treated with the algal extracts at a concentration chosen according to the cytotoxicity results (Table 1 ). The wells reserved for cell culture and virus control were not treated with the extracts. Afterwards, $100 \mu \mathrm{L}$ of a HMPV suspension diluted at $10^{-1}$ were added to treated and untreated cell cultures and incubated in a $5 \% \mathrm{CO}_{2}$ atmosphere at $34{ }^{\circ} \mathrm{C}$ for seven days. All experiments were carried out in triplicate.

After incubation the cell monolayer was washed with culture medium. The cells were lysated using guanidine thiocyanate buffer. The viral RNA was extracted and RT-PCR for HMPV was performed according to MACKAY et al. (2003) ${ }^{23}$. The RT-PCR product was analyzed by agarose gel electrophoresis stained with ethidium bromide. A 213 bp DNA fragment was observed for the viral control. The antiviral activity was evaluated comparing the intensity of the RT-PCR product obtained from the cell cultures in the presence of the extracts with that of the virus control that was inoculated in the same plate in an untreated cell culture.

6. Extraction of viral RNA: Viral RNA was extracted from the cells lysate using the commercial kit RNAgents RNA Total Isolation System (Promega Madison, USA), according to the manufactory's instructions.

7. RT-PCR for HMPV: The amplification of the viral RNA, was performed by using the methodology previously described by MACKAY et al. $(2003)^{23}$, with the primers MPV01.2 (AAC CGT GTA CTA AGT GAT GCA CTC) and MPV02.2 (CAT TGT TTG ACC GGC CCC ATA A), which amplified a fragment of $213 \mathrm{bp}$ of the nucleoprotein gene of the HMPV.

8. Determination of the mechanisms of action: Once the ability of the algal extract to inhibit the replication of the HMPV was established, several experiments were carried out to elucidate the mechanism involved in the antiviral activity. The experiments were designed in order to demonstrate whether the activity was on the viral particle (virucidal), on the virus-cell interaction (receptors and cell entry) or in a late stage of virus replication (intracellular activity).

8.1. Virucidal assay: $100 \mu \mathrm{L}$ of a HMPV suspension diluted at $10^{-1}$ was added to either $900 \mu \mathrm{L}$ of each extract or MEM-Eagle without serum (control), according to CHEN et al. (1988) $)^{9}$. All mixtures were incubated at $37{ }^{\circ} \mathrm{C}$ for two hours and, immediately after, they were inoculated in Vero cell monolayers grown in 48-well plates, which were incubated for seven days at $34{ }^{\circ} \mathrm{C}$ in atmosphere of $5 \% \mathrm{CO}_{2}$. After incubation the cell monolayer was washed with culture medium, the cells were lysated using guanidine thiocyanate buffer, the viral RNA was extracted and RT-PCR for HMPV was performed as described in 2.7.

8.2. Cellular receptors assay: In order to evaluate the possible effect of the extracts on cell receptors, each extract was added to Vero cell monolayers, incubated at $4{ }^{\circ} \mathrm{C}$ for one hour, washed three times with cold MEM-Eagle and $100 \mu \mathrm{L}$ of a HMPV suspension diluted at $10^{-1}$ was added to treated and untreated cell culture and incubated at $34{ }^{\circ} \mathrm{C}$ for seven days. After incubation the cell monolayer was washed with culture 


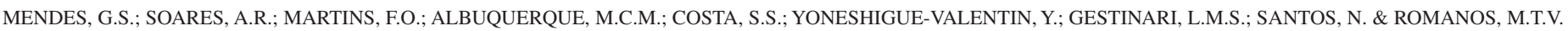
- Antiviral activity of the green marine alga Ulva fasciata on the replication of human metapneumovirus. Rev. Inst. Med. Trop. São Paulo, 52(1): 3-10, 2010.

Table 2

Anti-HMPV activity of the algal extracts

\begin{tabular}{|c|c|c|c|c|}
\hline Alga & Location & Extraction Method & Concentration used $(\mu \mathrm{g} / \mathrm{mL})$ & HMPV replication* \\
\hline \multirow[t]{7}{*}{ Ulva fasciata } & Rasa beach & Maceration & 25 & - \\
\hline & & Decoction & 100 & - \\
\hline & & Maceration of the decoction & 12.5 & - \\
\hline & Forno beach & Maceration & 25 & - \\
\hline & & Decoction & 100 & \pm \\
\hline & & Maceration of the decoction & 25 & + \\
\hline & & & Virus control & +++ \\
\hline
\end{tabular}

* (-) absence of viral replication (total inhibition); $(\underline{ \pm}++)$ partial inhibition; $(+++)$ no inhibition.

medium, the cells were lysated using guanidine thiocyanate buffer, the viral RNA was extracted and RT-PCR for HMPV was performed as described in 2.7 .

8.3. Cell entry assay: Vero cell monolayers were inoculated with $100 \mu \mathrm{L}$ of a HMPV suspension diluted at $10^{-1}$ and incubated for one hour at $4{ }^{\circ} \mathrm{C}$. After absorption of the inocula, the monolayers were washed, treated with the extracts, and incubated for one hour at $37^{\circ} \mathrm{C}$. Afterwards, the monolayers were washed, MEM-Eagle was added and the cells were incubated at $34{ }^{\circ} \mathrm{C}$ for seven days in an atmosphere of $5 \% \mathrm{CO}_{2}$. After incubation the cell monolayer was washed with culture medium, the cells were lysated using guanidine thiocyanate buffer, the viral RNA was extracted and RT-PCR for HMPV was performed as described in 2.7 .

8.4. Intracellular assay: Vero cell monolayers were inoculated with $100 \mu \mathrm{L}$ of a HMPV suspension diluted at $10^{-1}$ and incubated at $37{ }^{\circ} \mathrm{C}$ for two hours. After incubation, the cell monolayers were washed and added of each extract. Then, the cells were incubated at $37^{\circ} \mathrm{C}$ for $10 \mathrm{~h}$, washed, added of MEM-Eagle and incubated again at $34^{\circ} \mathrm{C}$ until seven days of infection were completed. After incubation, the cell monolayer was washed with culture medium, the cells were lysated using guanidine thiocyanate buffer, the viral RNA was extracted and RT-PCR for HMPV was performed as described in 2.7 .

\section{RESULTS}

1. Algal extracts: The three extracts of Ulva fasciata obtained from each place (Forno beach and Rasa beach) were analyzed by Thin Layer Chromatography (TLC). This analysis revealed clearly different chemical profiles between the two places. The extracts obtained by maceration and maceration of the decoction showed similar TLC profiles when compared within each site and showed presence of the same major secondary metabolites. The TLC analysis revealed also that, the composition of the decoct extracts was very different when compared to the organic extracts, showing only polar compounds as the majority.

The determination of the chemical profile by the use of ${ }^{1} \mathrm{H}$ NMR and ${ }^{13} \mathrm{C}$ NMR were made for the maceration and decoction maceration extracts from both sites. The ${ }^{1} \mathrm{H}$ NMR spectrum of maceration extract of $U$. fasciata from Forno beach shows the presence of triacylglycerols and a mixture of fatty acids as the major components. Strong ${ }^{1} \mathrm{H}$ signals at $\delta 4.29 \mathrm{ppm}(\mathrm{dd}, J=7.4 ; 14.6 \mathrm{~Hz}), 4.16 \mathrm{ppm}(\mathrm{dd}, J=6.0 ; 12.4 \mathrm{~Hz})$ and $5.36 \mathrm{ppm}(\mathrm{m})$, characteristics of triacylglycerols were observed. The strong signal related to end-chain methyl groups of fatty acids were clearly assigned at $\delta 0.88 \mathrm{ppm}(\mathrm{t}, J=7.2 \mathrm{~Hz})$. The signals at $\delta 2.31 \mathrm{ppm}$ $(\mathrm{t}, J=7.4 \mathrm{~Hz})$ and $1.60 \mathrm{ppm}(\mathrm{m})$ indicated the methylene protons $\alpha$ - and $\beta$-, respective to the carbonyl groups. Peaks at $\delta 2.80 \mathrm{ppm}$ and $2.02 \mathrm{ppm}$ indicated methylene protons next to the double bonds. A strong peak at $\delta 1.26 \mathrm{ppm}$ (bs) reference to the long chain of methylene groups was observed. Signals at $\delta 0.65 \mathrm{ppm}(\mathrm{s}), 0.92 \mathrm{ppm}(\mathrm{s})$ and $1.0 \mathrm{ppm}(\mathrm{s})$ demonstrated a small quantity of sterols in the extract.

The ${ }^{13} \mathrm{C}$ NMR spectrum of the decoction extract from Forno beach showed resonances of fatty acids carboxylic groups and the signals behind $60-70 \mathrm{ppm}$ indicated the presence of glycerol moiety. The same major components were observed in the spectrum of maceration of the decoction extract from Forno beach.

The maceration and maceration of the decoction extracts of the $U$. fasciata from Rasa beach showed both free fatty acids and methyl ester of fatty acids. The signal of the methyl ester was observed at $\delta 3.70 \mathrm{ppm}$ (bs). The small quantity of sterols was observed again.

The chemical profile of decoction extracts was determined by IR analyses. Absorption bands at 3240, 2359, 1630, 1266 and $741 \mathrm{~cm}^{-1}$ suggested the presence of the sulfate polysaccharides in the crude extract from Forno beach. In the decoction extract of Rasa beach, absorption bands at 3305, 1658, 1431, 1105 and $605 \mathrm{~cm}^{-1}$ were observed.

2. Cytotoxicity: Experiments to evaluate the cytotoxicity of the extracts were performed before carrying out the antiviral assays. The results are shown in Table 1. For the antiviral experiments we used a concentration where at least $80 \%$ of the cell culture was viable.

3. Antiviral activity: As shown in Fig. 1 and Table 2, four out of the six extracts inhibited nearly $100 \%$ of viral replication at $12.5 \sim 100$ $\mu \mathrm{g} / \mathrm{mL}$ since no viral RNA amplification was detected in the cells lysate after RT-PCR, as demonstrated by the absence of the characteristic $213 \mathrm{bp}$ DNA fragment in the agarose gel. The remaining two extracts (U. fasciata from Forno beach obtained by decoction and maceration of decoction) presented only partial inhibition. Although the characteristic PCR product had been observed, its intensity in the agarose gel was significantly lower than that of the untreated viral control culture. 
MENDES, G.S.; SOARES, A.R.; MARTINS, F.O.; ALBUQUERQUE, M.C.M.; COSTA, S.S.; YONESHIGUE-VALENTIN, Y.; GESTINARI, L.M.S.; SANTOS, N. \& ROMANOS, M.T.V. - Antiviral activity of the green marine alga Ulva fasciata on the replication of human metapneumovirus. Rev. Inst. Med. Trop. São Paulo, 52(1): 3-10, 2010.

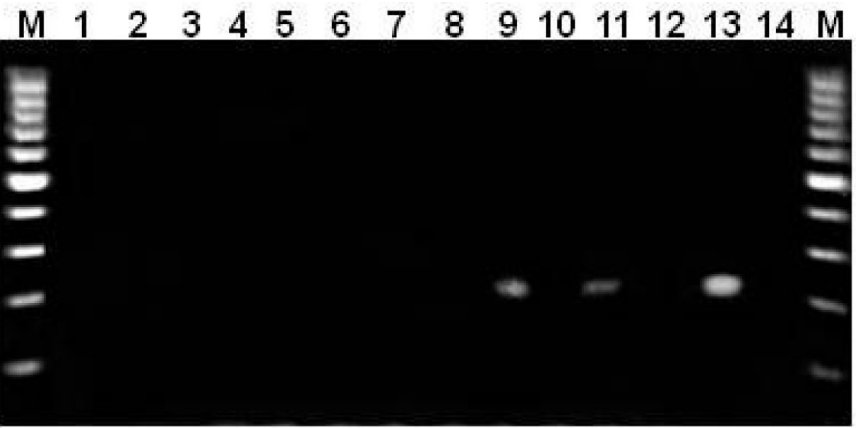

Fig. 1 - Antiviral activity of several extracts of $U$. fasciata on the replication of human metapneumovirus. $100 \mu \mathrm{L}$ of a HMPV suspension diluted at $10^{-1}$ were added to Vero cell cultures treated and untreated with algal extracts. After incubation at $34{ }^{\circ} \mathrm{C}$ for 7 days the cell monolayer was washed, lysated, the viral RNA was extracted and RT-PCR for HMPV was performed. The RT-PCR product was analyzed and the antiviral activity was evaluated comparing the intensity of the RT-PCR product obtained from the cell cultures treated and untreated. M - 100bp molecular marker (Fermentas); lines 1, 3 and 5 - extracts of $U$. fasciata obtained from Rasa beach + HMPV: extract prepared by maceration (1) $(25 \mu \mathrm{g} /$ $\mathrm{mL})$, decoction (3) $(100 \mu \mathrm{g} / \mathrm{mL})$, and maceration of decoction (5) $(12.5 \mu \mathrm{g} / \mathrm{mL})$; lines 2 , 4 and 6, same extracts without the HMPV (substance control). Lines 7, 9 and 11 - extracts of $U$. fasciata obtained from Forno beach + HMPV: extract prepared by maceration (7) (25 $\mu \mathrm{g} / \mathrm{mL})$, decoction (9) (100 $\mu \mathrm{g} / \mathrm{mL})$, and maceration of decoction (11) $(25 \mu \mathrm{g} / \mathrm{mL})$; lines 8 , 10 and 12, same extracts without the HMPV (substance control); line 13 - HMPV positive control; line 14 - cell culture control.

\section{Mechanisms of action}

4.1. Virucidal activity: As demonstrated in Fig. 2 and Table 3, five extracts presented virucidal activity. The exception was the extract of $U$. fasciata seaweed from Rasa beach obtained by decoction.

4.2. Cellular receptors inhibition: The activity on cellular receptors was better observed in the extracts of the algae collected from Forno beach, prepared by maceration and maceration of decoction. The extracts from Rasa beach prepared by maceration and maceration of decoction, also presented activity, although to a lower degree. The extracts prepared by decoction, from the algae collected from both sites, did not show activity at this stage of the viral replication (Fig. 3, Table 3).

4.3. Cell entry inhibition: The extract of $U$. fasciata from Forno beach prepared by maceration of the decoction, was the only extract that completely inhibited that stage of viral replication. The others also presented activity in this stage of the viral cycle, but to a lower degree (Fig. 4 and Table 3).

4.4. Intracellular inhibition: Only the extract from Forno beach, prepared by maceration presented intracellular activity (Fig. 5 and Table 3).

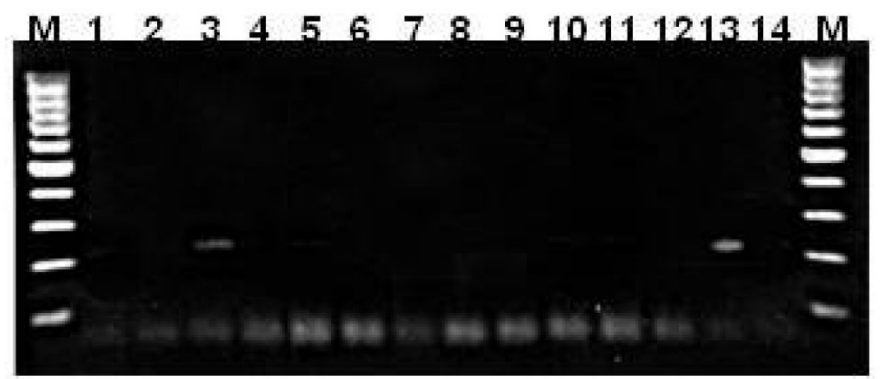

Fig. 2 - Human metapneumovirus virucidal activity of several extracts of $U$. fasciata. $100 \mu \mathrm{L}$ of a HMPV suspension diluted at $10^{-1}$ was added to either $900 \mu \mathrm{L}$ of each extract or MEMEagle (control), incubated at $37^{\circ} \mathrm{C}$ for two hours and inoculated in Vero cell monolayers. After incubation for 7 days at $34{ }^{\circ} \mathrm{C}$ in atmosphere of $5 \% \mathrm{CO}_{2}$ the cell monolayer was washed, lysated, viral RNA was extracted and RT-PCR for HMPV was performed. The RTPCR product was analyzed and the antiviral activity was evaluated comparing the intensity of the RT-PCR product obtained from the viral suspension treated and untreated. M - 100bp molecular marker (Fermentas); lines 1, 3 and 5 - extracts of $U$. fasciata obtained from Rasa beach + HMPV: extract prepared by maceration (1) $(25 \mu \mathrm{g} / \mathrm{mL})$, decoction (3) $(100 \mu \mathrm{g} / \mathrm{mL})$, and maceration of decoction (5) $(12.5 \mu \mathrm{g} / \mathrm{mL})$; lines 2, 4 and 6 , same extracts without the HMPV (substance control). Lines 7, 9 and 11 - extracts of $U$. fasciata obtained from Forno beach + HMPV: extract prepared by maceration (7) $(25 \mu \mathrm{g} / \mathrm{mL})$, decoction (9) $(100 \mu \mathrm{g} / \mathrm{mL})$, and maceration of decoction (11) $(25 \mu \mathrm{g} / \mathrm{mL})$; lines 8,10 and 12 , same extracts without the HMPV (substance control); line 13 - HMPV positive control; line 14 - cell culture control.

Table 3

Results of the mechanism of action assays

\begin{tabular}{|c|c|c|c|c|c|c|c|}
\hline Alga & Location & $\begin{array}{l}\text { Extraction } \\
\text { Method }\end{array}$ & $\begin{array}{l}\text { Concentration } \\
(\mu \mathrm{g} / \mathrm{mL})\end{array}$ & Virucidal $^{*}$ & Receptor & Penetration & Intracelular \\
\hline \multirow[t]{7}{*}{ Ulva fasciata } & Rasa beach & Maceration & 25 & - & ++ & ++ & +++ \\
\hline & & Decoction & 100 & +++ & +++ & ++ & +++ \\
\hline & & $\begin{array}{l}\text { Maceration of the } \\
\text { decoction }\end{array}$ & 12.5 & - & + & ++ & +++ \\
\hline & Forno beach & Maceration & 25 & - & - & ++ & - \\
\hline & & Decoction & 100 & - & +++ & ++ & +++ \\
\hline & & $\begin{array}{l}\text { Maceration of the } \\
\text { decoction }\end{array}$ & 25 & - & - & - & +++ \\
\hline & & Virus control & & +++ & +++ & +++ & +++ \\
\hline
\end{tabular}

\footnotetext{
* $(-)$ absence of viral replication (total inhibition); $(+/+)$ partial inhibition; $(+++)$ no inhibition.
} 


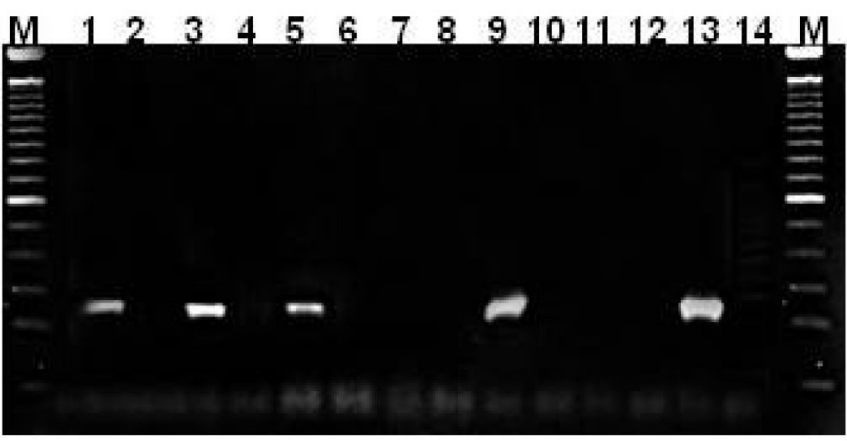

Fig. 3 - Inhibition of HMPV-cellular receptors by several extracts of $U$. fasciata. Algal extracts were added to Vero cell monolayers, incubated one hour at $4{ }^{\circ} \mathrm{C}$, washed three times with cold MEM-Eagle and $100 \mu \mathrm{L}$ of a HMPV suspension diluted at $10^{-1}$ was added to treated and untreated cell culture and incubated at $34^{\circ} \mathrm{C}$ for seven days in an atmosphere of $5 \% \mathrm{CO}_{2}$. After incubation the cell monolayer was washed, lysated, the viral RNA was extracted and RT-PCR for HMPV was performed. The RT-PCR product was analyzed and the antiviral activity was evaluated comparing the intensity of the RT-PCR product obtained from the cell cultures, treated and untreated. M - 100bp molecular marker (Fermentas); lines 1, 3 and 5 - extracts of $U$. fasciata obtained from Rasa beach + HMPV: extract prepared by maceration (1) (25 $\mu \mathrm{g} / \mathrm{mL})$, decoction (3) $(100 \mu \mathrm{g} / \mathrm{mL})$, and maceration of decoction (5) $(12.5 \mu \mathrm{g} / \mathrm{mL})$; lines 2 , 4 and 6, same extracts without the HMPV (substance control). Lines 7, 9 and 11 - extracts of $U$. fasciata obtained from Forno beach + HMPV: extract prepared by maceration (7) (25 $\mu \mathrm{g} / \mathrm{mL})$, decoction (9) (100 $\mu \mathrm{g} / \mathrm{mL})$, and maceration of decoction (11) $(25 \mu \mathrm{g} / \mathrm{mL})$; lines 8 , 10 and 12, same extracts without the HMPV (substance control); line 13 - HMPV positive control; line 14 - cell culture control.

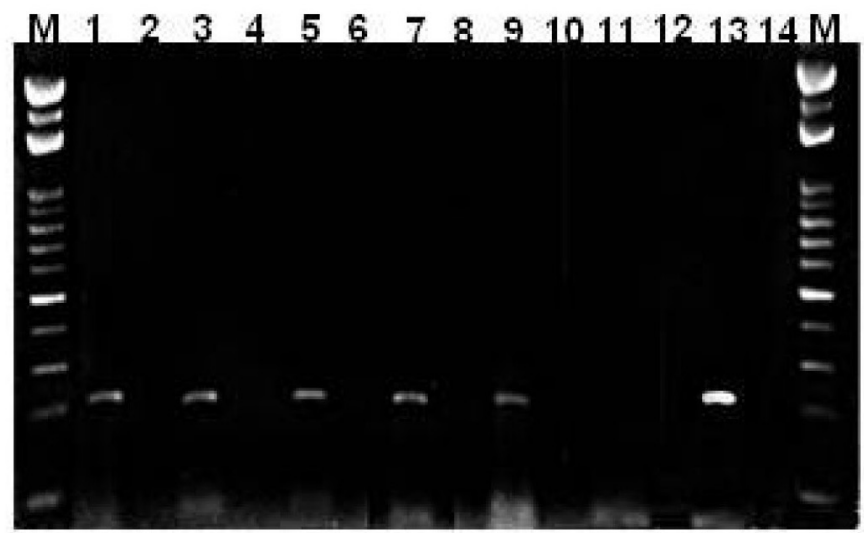

Fig. 4 - Inhibition of HMPV cell entry by several extracts of $U$. fasciata. Vero cell monolayers were inoculated $100 \mu \mathrm{L}$ with a HMPV suspension diluted at $10^{-1}$ and incubated by one hour at $4{ }^{\circ} \mathrm{C}$. After adsorption, the monolayers were washed, treated with the extracts, and incubated for one hour at $37^{\circ} \mathrm{C}$. Afterwards, the monolayers were washed, MEM-Eagle was added and the cells were incubated at $34{ }^{\circ} \mathrm{C}$ for seven days in atmosphere of $5 \% \mathrm{CO}_{2}$. After incubation the cell monolayer was washed, lysated, the viral RNA was extracted and RT-PCR for HMPV was performed. The RT-PCR product was analyzed and the antiviral activity was evaluated comparing the intensity of the RT-PCR product obtained from the cell cultures treated and untreated. M - 100bp molecular marker (Fermentas); lines 1, 3 and 5 - extracts of $U$. fasciata obtained from Rasa beach + HMPV: extract prepared by maceration (1) (25 $\mu \mathrm{g} / \mathrm{mL})$, decoction (3) $(100 \mu \mathrm{g} / \mathrm{mL})$, and maceration of decoction (5) $(12.5 \mu \mathrm{g} / \mathrm{mL})$; lines 2 , 4 and 6, same extracts without the HMPV (substance control). Lines 7, 9 and 11 - extracts of $U$. fasciata obtained from Forno beach + HMPV: extract prepared by maceration (7) (25 $\mu \mathrm{g} / \mathrm{mL})$, decoction (9) (100 $\mu \mathrm{g} / \mathrm{mL})$, and maceration of decoction (11) $(25 \mu \mathrm{g} / \mathrm{mL})$; lines 8 , 10 and 12, same extracts without the HMPV (substance control); line 13 - HMPV positive control; line 14 - cell culture control.

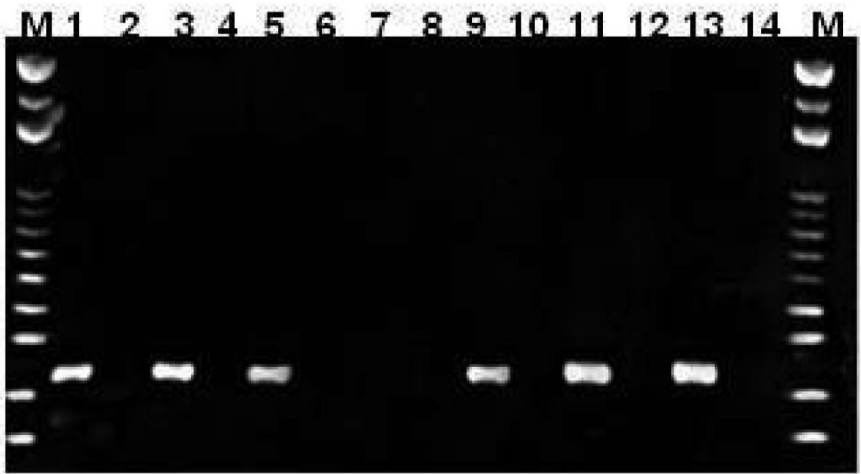

Fig. 5 - Intracellular inhibition of HMPV replication by several extracts of $U$. fasciata. Vero cell monolayers were inoculated with $100 \mu \mathrm{L}$ of a HMPV suspension diluted at $10^{-1}$ and incubated at $37{ }^{\circ} \mathrm{C}$ for two hours. After incubation, the cell monolayers were washed and added to each extract and incubated at $37^{\circ} \mathrm{C}$ for $10 \mathrm{~h}$, washed, added to MEM-Eagle and again incubated at $34{ }^{\circ} \mathrm{C}$ in an atmosphere of $5 \% \mathrm{CO}_{2}$ until it completed seven days of infection. After incubation the cell monolayer was washed, lysated, the viral RNA was extracted and RTPCR for HMPV was performed. The RT-PCR product was analyzed and the antiviral activity was evaluated comparing the intensity of the RT-PCR product obtained from the cell cultures treated and untreated. M - 100bp molecular marker (Fermentas); lines 1, 3 and 5 - extracts of $U$. fasciata obtained from Rasa beach + HMPV: extract prepared by maceration (1) (25 $\mu \mathrm{g} / \mathrm{mL})$, decoction (3) $(100 \mu \mathrm{g} / \mathrm{mL})$, and maceration of decoction (5) $(12.5 \mu \mathrm{g} / \mathrm{mL})$; lines 2 , 4 and 6, same extracts without the HMPV (substance control). Lines 7, 9 and 11 - extracts of $U$. fasciata obtained from Forno beach + HMPV: extract prepared by maceration (7) (25 $\mu \mathrm{g} / \mathrm{mL})$, decoction (9) $(100 \mu \mathrm{g} / \mathrm{mL})$, and maceration of decoction (11) $(25 \mu \mathrm{g} / \mathrm{mL})$; lines 8 , 10 and 12, same extracts without the HMPV (substance control); line 13 - HMPV positive control; line 14 - cell culture control.

\section{DISCUSSION}

Recently, the interest on study biomolecules obtained from marine organism is increasing due to the enormous biotechnological potential of such compounds. Herein we evaluated the inhibitory activity of six extracts obtained from the alga U. fasciata against HMPV. The algae were collected in two different places (Forno beach and Rasa beach) in the city of Búzios, Brazil.

The Ulva genus has a global distribution, and the potential pharmacological application of its compounds have been investigated. Species with algaecide activity ${ }^{2}$, antibiotic and antifungal ${ }^{4}$, and antiviral activity $^{19}$ have already been described. The same species used in this work, U. fasciata, was already described as a powerful inhibitor of the replication of HSV- $1^{39}$ and HTLV-1 ${ }^{32}$.

It is known that environmental factors intervene with the production of the biomass of marine algae $e^{6}$ and, it is believed that these factors can also influence the production of bioactive components in these algae and, influence its biological activities ${ }^{32,36,44,52}$. Therefore extracts of $U$. fasciata collected from different regions were tested. Moreover, the extracts were prepared by three distinct methodologies: maceration, decoction and maceration of decoction. With this, antiviral evaluation of different groups of molecules was allowed, since each method aims at the attainment of different groups of constituent.

The preparation of extracts by maceration used a mixture of organic solvents (dichloromethane:methanol, 1:1). In general these solvents 


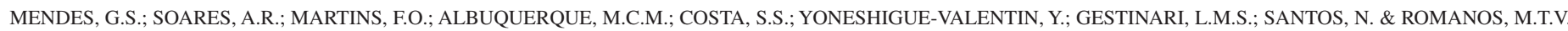
- Antiviral activity of the green marine alga Ulva fasciata on the replication of human metapneumovirus. Rev. Inst. Med. Trop. São Paulo, 52(1): 3-10, 2010.

select low-molecular compounds that present intermediate polarity such as terpenic and halogenic components, fatty acids and phenolic substances. In the extracts prepared by decoction, in which the algae were boiled in distilled water, the molecules obtained are hydrophilic, possibly macromolecules, for example, proteins and polysaccharides. In the case of the extracts prepared by maceration of decoction, because the solvent used was methanol, the substances found in this extract possess the same characteristics as the ones found in the macerated extracts described above, however, the fact that the material had been previously boiled could lead to the structural modification or evaporation of some of the molecules.

Organic components have been identified in algae of Ulva genus. Simple bromophenols, especially 2,4,6-tribromophenol ${ }^{15}$, lipid components ${ }^{33,38}$, dimethylsulfoniopropionate (DMSP) have been largely described for this genus ${ }^{44,45}$. In this work, we identified a mixture of the lipids as the major component at the maceration and maceration of the decoction extracts from both places. Tryacylglycerols and free fatty acids were observed as the major components in the extracts from Forno beach. In the crude extracts from Rasa beach, free fatty acids and methyl ester of fatty acids were observed as the major components. In all the organic extracts, a small quantity of sterols was observed. The Ulva genus is known to produce different polysaccharide ${ }^{19,21,22}$. In relation to the decoction extracts, the IR absorption bands should be an indication of the presence of sulfate polysaccharides in both the extracts.

The three extracts of the algae collected at Rasa beach presented excellent inhibitory activity against HMPV despite the method used for its preparation, while only the extract prepared by maceration from the algae collected at Forno beach presented similar activity. The other two extracts prepared by decoction and maceration of decoction showed only partial inhibition of the viral replication.

Although the chemical profiles of the major constituents have been observed in the organic extracts by the NMR analysis, the composition of the minor components in the extracts were not observed. The ${ }^{1} \mathrm{H}$ NMR spectroscopy technique has already been applied as a tool for the analysis of lipid mixtures. However, ${ }^{1} \mathrm{H}$ NMR spectra of lipid mixtures show only the resonances of all "NMR-visible" components that are above the detection threshold. Also, the ${ }^{1} \mathrm{H}$ NMR spectra of lipid mixtures often show only broad peaks, due to the partial overlap of several resonances arising from chemically similar protons in different molecules of the same classes. Thus, the information obtained from one-dimensional NMR spectroscopy is limited to the relative concentrations of some of the majority components. The results showed that the activity observed in the extracts could be related to the minor components or to the concentration of the active molecules

In general, the algal extracts present low toxicity for cell cultures ${ }^{1,24,37,48}$. The same was observed in this work. The extracts obtained by decoction, regardless of the place of sampling, presented a lower toxicicity than those obtained by maceration or maceration of decoction. Although most protocols use drug concentrations in which $50 \%$ of the cells remains viable, this amount of cells is quite small and could interfere with the antiviral tests, generating false results. The ideal condition of cell viability would be around $100 \%$ of viable cells. However, for some extracts, this concentration would have been very low (data not shown), a fact which could also mask the activity of the extract. Therefore, the concentration of the extracts used for the experiments was chosen to ensure that at least $80 \%$ of the cells in culture had remained viable ${ }^{29}$.

Because all the extracts showed some level of viral inhibition, more tests were conducted in order to investigate the mechanism involved in the antiviral activity. The results demonstrated that the majority of the extracts (five out of six) possess virucidal activity and therefore have the ability to interact with the extracellular viral particles and prevent the infection. On the other hand, only two extracts (from Forno beach, obtained by maceration and maceration of the decoction) were able to interact with cell receptors, hindering the viral entry. Finally, only the extract of samples from Forno beach obtained by maceration presented intracellular activity.

The extract obtained by maceration of decoction from the algae collected in Forno beach presented the most significant antiviral activity, possibly because two different mechanisms were involved: virucidal and inhibition of cell entry. These differences of activities between the extracts can be explained by the different abiotic conditions in which the seaweed grew such as, temperature, nutritional conditions and salinity of the water. This strengthens the theory of BRAVIN \& YONESHIGUEVALETIN that environmental factors are able to influence the production of the compounds of the marine algae ${ }^{6}$, since these conditions vary from one place of collection to another.

Another factor that can be associated to the different activities presented by the extracts is the method used to obtain them. Most of the research on antiviral activity of marine algae had focused on the role of sulfated polysaccharides ${ }^{14,17,40,51}$ which are large negatively charged molecules, which makes it difficult for such molecules to have an intracellular activity, although intracellular activity has already been described for a sulfated polysaccharide ${ }^{16}$. This type of components was observed in the extracts prepared by decoction.

The molecules found in extracts prepared by maceration with organic solvents are smaller, facilitating the entry into the cell, thus explaining the intracellular activity of the extract of $U$. fasciata collected from Forno beach prepared by maceration. It could also explain the excellent activity observed during the cell entry stage of the viral cycle observed for the extract prepared by maceration of the decoction of the algae collected at the same place.

To our knowledge, this is a pioneer study on antiviral activity of marine algae against HMPV. It is also the first study on antiviral activity against HMPV ever done in Brazil. The study also shows the effect of different environment and different chemical procedures used to obtain the extract on its biological properties. Based on the present findings it could also be inferred that bioassay guided by fractionation and purification of $U$. fasciata active extracts may produce potent bioactive compounds.

\section{RESUMO}

\section{Atividade antiviral da alga verde marinha Ulva fasciata na replicação do metapneumovírus humano}

Neste artigo, foi avaliada a atividade antiviral da alga marinha Ulva fasciata, coletada nas Praias do Forno e Rasa, em Búzios, Rio de Janeiro, Brasil, sobre a replicação do metapneumovírus humano (HMPV). 
MENDES, G.S.; SOARES, A.R.; MARTINS, F.O.; ALBUQUERQUE, M.C.M.; COSTA, S.S.; YONESHIGUE-VALENTIN, Y.; GESTINARI, L.M.S.; SANTOS, N. \& ROMANOS, M.T.V. - Antiviral activity of the green marine alga Ulva fasciata on the replication of human metapneumovirus. Rev. Inst. Med. Trop. São Paulo, 52(1): 3-10, 2010.

Os extratos desta alga foram preparados utilizando três diferentes metodologias, visando a comparação da atividade de diferentes grupos de compostos químicos que são obtidos dependendo da metodologia empregada. Quatro, do total de seis extratos foram capazes de inibir praticamente $100 \%$ da replicação viral. Os resultados demonstram também que a maioria dos extratos (cinco, dos seis), possui atividade virucida e, portanto, possuem a habilidade de interagir com a partícula viral extracelularmente impedindo a infecção. Por outro lado, apenas dois extratos (coletado da Praia do Forno e, preparado através de maceração e maceração do decocto) foram capazes de se ligar a receptores celulares, impossibilitando assim a entrada das partículas virais nas células. Finalmente, apenas o extrato que foi preparado por maceração da alga coletada na Praia do Forno, demonstrou atividade intracelular. Até onde sabemos, este é um estudo pioneiro sobre a atividade antiviral de algas marinhas sobre o HMPV. É também o primeiro estudo sobre atividade antiviral sobre HMPV realizado no Brasil. O estudo também mostra o efeito de diferentes condições ambientais e procedimentos químicos utilizados na preparação do extrato sobre suas propriedades biológicas.

\section{ACKNOWLEDGMENTS}

We thank Soluza dos Santos Gonçalves for the technical assistance. This study was supported in part by Conselho Nacional de Desenvolvimento Científico e Tecnológico (CNPq), Coordenação de Aperfeiçoamento de Pessoal de Nível Superior (CAPES) and, Fundação Carlos Chagas de Amparo à Pesquisa do Estado do Rio de Janeiro (FAPERJ), Brazil.

\section{REFERENCES}

1. Adhikari U, Mateu CG, Chattopadhyay K, Pujol CA, Damonte EB, Ray B. Structure and antiviral activity of sulfated fucans from Stoechospermum marginatu. Phytochemistry. 2006;67:2474-82.

2. Alamsjah MA, Hirao S, Ishibashi F, Fujita Y. Isolation and structure determination of algicidal compounds from Ulva fasciata. Biosci Biotechnol Biochem. 2005;69:218692.

3. Albuquerque MC, Pena GP, Varella RB, Gallucci G, Erdman D, Santos N. Novel respiratory virus infections in children, Brazil. Emerg Infect Dis. 2009;15:806-8.

4. Awad NE. Biologically active steroid from the green alga Ulva lactuca. Phytother Res. 2000;14:641-3.

5. Bellei N, Carraro E, Perosa A, Watanabe A, Arruda E, Granato C. Acute respiratory infection and influenza-like illness viral etiologies in Brazilian adults. J Med Virol. 2008;80:1824-7.

6. Bravin IC, Yoneshigue-Valentin Y. Influência de fatores ambientais sobre o crescimento in vitro de Hypnea musciformis (Wulfen) Lamouroux (Rhodophyta). Rev Bras Bot. 2002;25:469-74.

7. Canducci F, Debiaggi M, Sampaolo M, Marinozzi MC, Berre S, Terulla C, et al. Two-year prospective study of single infections and co-infections by respiratory syncytial virus and viruses identified recently in infants with acute respiratory disease. J Med Virol. 2008;80:716-23

8. Carneiro BM, Yokosawa J, Arbiza J, Costa LF, Mirazo S, Nepomuceno LL, et al. Detection of all four human metapneumovirus subtypes in nasopharyngeal specimens from children with respiratory disease in Uberlândia, Brazil. J Med Virol. 2009;81:1814-18.

9. Chen M, Griffith BP, Lucia HL, Hsiung GD. Efficacy of S26308 against guinea pig cytomegalovirus infection. Antimicrob Agents Chemother. 1988;32: 678-83.
10. Damonte EB, Neyts J, Pujol CA, Snoeck R, Andrei G, Ikeda S, et al. Antiviral activity of a sulphated polysaccharide from the red seaweed Nothogenia fastigiata. Biochem Pharmacol. 1994;47:2187-92.

11. Damonte EB, Matulewicz MC, Cerezo AS, Coto CE. Herpes simplex virus - inhibitory sulfated xylogalactans from the red seaweed Nothogenia fastigiata. Chemotherapy. 1996;42:57-64

12. Deffrasnes C, Hamelin ME, Boivin G. Human metapneumovirus. Semin Respir Crit Care Med. 2007;28:213-21

13. Dieg EF, Ehresmann DW, Hatch MT, Riedlinger DJ. Inhibition of herpesvirus replication by marine algae extracts. Antimicrob Agents Chemother. 1974;6:524-5.

14. Duarte ME, Noseda DG, Noseda MD, Tulio S, Pujol CA, Damonte EB. Inhibitory effect of sulfated galactans from the marine alga Bostrychia montagnei on herpes simplex virus replication in vitro. Phytomedicine. 2001;8:53-8.

15. Flodin C, Whitfield FB. 4-Hydroxybenzoic acid: a likely precursor of 2,4,6-tribromophenol in Ulva lactuca. Phytochemistry. 1999;51:249-55.

16. Gonzalez ME, Alarcón B, Carrasco L. Polysaccharides as antiviral agents: antiviral activity of Carrageenan. Antimicrob Agents Chemother. 1987;3:1388-93.

17. Haslin C, Lahaye M, Pellegrini M, Chermann JC. In vitro anti-HIV activity of sulfated cell-wall polysaccharides from gametic, carposporic and tetrasporic stages of the Mediterranean red alga Asparagopsis armata. Planta Med. 2001;67:301-5.

18. Hasui M, Matsuda M, Okutani K, Shigeta S. In vitro antiviral activities of sulfated polysaccharides from a marine microalga (Cochlodinium polykrikoides) against human immunodeficiency virus and other enveloped viruses. Int J Biol Macromol. 1995; 17:293-7.

19. Ivanova V, Rouseva R, Kolarova M, Serkedjieva J, Rachev R, Manolova N. Isolation of a polysaccharide with antiviral effect from Ulva lactuca. Prep Biochem. 1994;24:83-97.

20. Kahn JS. Newly discovered respiratory viruses: significance and implications. Curr Opin Pharmacol. 2007;7:478-83.

21. Lahaye M, Ray B. Cell-wall polysaccharides from the marine green alga Ulva "rigida" (Ulvales, Chlorophyta) - NMR analysis of ulvan oligosaccharides. Carbohydr Res. 1996;283:161-73.

22. Leiro JM, Castro R, Arranz JA, Lamas J. Immunomodulating activities of acidic sulphated polysaccharides obtained from the seaweed Ulva rigida. C Agardh Int Immunopharmacol. 2007; 7:879-88.

23. Mackay IM, Jacob KC, Woolhouse D, Walker K, Syrmis MW, Whiley DM. Molecular assays for detection of human metapneumovirus. J Clin Microbiol. 2003;41:100-5.

24. Mandal P, Mateu CG, Chattopadhyay K, Pujol CA, Damonte EB, Ray B. Structural features and antiviral activity of sulphated fucans from the brown seaweed Cystoseira indica. Antivir Chem Chemother. 2007;18:153-62.

25. Manoha C, Espinosa S, Aho SL, Huet F, Pothier P. Epidemiological and clinical features of HMPV, RSV and RVs infections in young children. J Clin Virol. 2007;38:221-6.

26. Mayer AMS, Hamann MT. Marine pharmacology in 2000: marine compounds with antibacterial, anticoagulant, antifungal, anti-inflammatory, antimalarial, antiplatelet, antituberculosis, and antiviral activities; affecting the cardiovascular, immune, and nervous systems and others miscellaneous mechanisms of action. Mar Biotechnol. (NY). 2004;6:37-52.

27. Mayer AMS, Rodríguez AD, Berlinck RGS, Hamann MT. Marine pharmacology in 20034: marine compounds with antihelmintic, antibacterial, anticoagulant, antifungal, anti-inflammatory, antimalarial, antiplatelet, antiprotozoal, antituberculosis, and antiviral activities; affecting the cardiovascular, immune, and nervous systems and others miscellaneous mechanisms of action. Comp Biochem Physiol C Toxicol Pharmacol. 2007; 145:553-81. 
MENDES, G.S.; SOARES, A.R.; MARTINS, F.O.; ALBUQUERQUE, M.C.M.; COSTA, S.S.; YONESHIGUE-VALENTIN, Y.; GESTINARI, L.M.S.; SANTOS, N. \& ROMANOS, M.T.V. - Antiviral activity of the green marine alga Ulva fasciata on the replication of human metapneumovirus. Rev. Inst. Med. Trop. São Paulo, 52(1): 3-10, 2010.

28. Monto A. Epidemiology of viral respiratory infections. Am J Med. 2002;112:4S-12S

29. Neyndorff HC, Bartel DL, Tufaro F, Levy JG. Development of a model to demonstrate photosensitized-mediated viral inactivation in blood. Transfusion. 1990;30:485-90.

30. Nicholson KG, Mcnally T, Silverman M, Simons P, Stockton JD, Zambon MC. Rates of hospitalization for influenza, respiratory syncytial virus and human metapneumovirus among infants and young children. Vaccine. 2006;24:102-8.

31. Oliveira DB, Durigon EL, Carvalho AC, Leal AL, Souza TS, Thomazelli LM, et al. Epidemiology and genetic variability of human metapneumovirus during a 4-yearlong study in Southeastern Brazil. J Med Virol. 2009;81:915-21.

32. Pereira RC, Soares AR, Teixeira VL, Villaca R, Da Gama BAP. Variation in chemical defenses against herbivore in southwestern Atlantic Stypopodium zonale (Phaeophyta). Botanica Marina. 2004;47:202-8

33. Pollesello P, Toffanin R, Eriksson O, Kilpeläinen I, Hynninen PH, Paoletti S, et al. Analysis of lipids in crude extracts by $13 \mathrm{C}$ nuclear magnetic resonance. Anal Biochem. $1993 ; 214: 238-44$

34. Pujol CA, Coto CE, Damonte EB. Determination of the antiviral activity of a naturally occurring sulfated xylomannan under various experimental conditions. Rev Argent Microbiol. 1995;27:91-8.

35. Riccetto AG, Silva LH, Spilki FR, Morcillo AM, Arns CW, Baracat EC. Genotype and clinical data of respiratory syncytial virus and metapneumovirus in Brazilian infants: a new perspective. Braz J Infect Dis. 2009;13: 35-9.

36. Rodde RSH, Varum KM, Larsen BA, Myklestad SM. Seasonal and geographical variation in the chemical composition of the red alga Palmaria palmata (L.) Kuntze. Botanica Marina. 2004;47:125-33.

37. Romanos MTV, Andrada-Serpa MJ, Santos MGM, Ribeiro ACF, Yoneshigue-Valentin $\mathrm{Y}$, Costa SS, et al. Inhibitory effect of extracts of Brazilian marine algae on human T-cell lymphotropic virus type 1 (HTLV-1)-induced syncytium formation in vitro. Cancer Invest. 2002;20:46-54.

38. Sanina NM, Goncharova SN, Kostetsky EY. Seasonal changes of fatty acid composition and thermotropic behavior of polar lipids from marine macrophytes. Phytochemistry. 2008;69:1517-27.

39. Santos MGM, Lagrota MHC, Miranda MMFS, Yoneshigue-Valentin Y, Wigg MD. A screening for the antiviral effect of extracts from Brazilian marine algae against acyclovir resistant herpes simplex virus type 1. Botanica Marina. 1999;42:227-30.

40. Schaeffer DJ, Krylov VS. Anti-HIV activity of extracts and compounds from algae and cyanobacteria. Ecotoxicol Environ Saf. 2000;45:208-27.

41. Schildgen O, Glatzel T, Geikowski T, Scheibner B, Matz B, Bindl L, et al. Human metapneumovirus RNA in encephalitis patient. Emerg Infect Dis. 2005;11:467-70.

42. Serkedjieva J. Antiviral activity of the red marine alga Ceramium rubrum. Phytother.
Res. 2004;18:480-83.

43. Sloots TP, Whiley DM, Lambert SB, Nissen MD. Emerging respiratory agents: new viruses for old diseases. J Clin Virol. 2008;42:233-43.

44. Van Alstyne KL, Pelletreau KN, Rosario K. The effects of salinity on Dimethylsulfoniopropionate production in the green alga Ulva fenestrata Postels et Ruprecht (Chlorophyta). Botanica Marina. 2003;46:350-6.

45. Van Alstyne KL, Koellermeier L, Nelson TA. Spatial variation in dimethylsulfoniopropionate (DMSP) production in Ulva lactuca (Chlorophyta) from the Northeast Pacific. Mar Biol. 2007; 150:1127-35.

46. Van Den Hoogen BG, De Jong JC, Groen J, Kuiken T, de Groot R, Fouchier RA, et al. A newly discovered human pneumovirus isolated from young children with respiratory tract disease. Nat Med. 2001;7:719-24

47. van Den Hoogen BG, Van Doornum GJ, Fockens JC, Cornelisse JJ, Beyer WE, de Groot $\mathrm{R}$, et al. Prevalence and clinical symptoms of human metapneumovirus infection in hospitalized patients. J Infect Dis. 2003;188:1571-7.

48. Wang SC, Bligh SW, Shi SS, Wang ZT, Hu ZB, Crowder J, et al. Structural features and anti-HIV-1 activity of novel polysaccharides from red algae Grateloupia longifolia and Grateloupia filicina. Int J Biol Macromol. 2007;41:369-75.

49. Weigl JAI, Puppe W, Meyer CU, Berner R, Foster J, Schmitt HJ, et al. Ten years' experience with year-round active surveillance of up to 19 respiratory pathogens in children. Eur J Pediatr. 2007;166:957-66.

50. Williams JV, Harris PA, Tollesfson SJ, Halbarnt-Rush LL, Pingsterhaus JM, Edwards, $\mathrm{KM}$, et al. Human metapneumovirus and lower respiratory tract disease in otherwise healthy infants and children. N Engl J Med. 2004;350:443-50.

51. Witvrouw M, De Clercq E. Sulfated polysaccharides extracted from sea algae as potential antiviral drugs. Gen Pharmacol. 1997;29:497-511.

52. Wright JT, De Nys R, Steinberg PD. Geographic variation in halogenated furanones from the red alga Delisea pulchra and associated herbivores and epiphytes. Mar Ecol Prog Ser. 2000;207:227-41.

53. Wyde PR, Chetty SN, Jewell AM, Boivin G, Piedra PA. Comparison of the inhibition of human metapneumovirus and respiratory syncytial virus by ribavirin and immune serum globulin in vitro. Antiviral Res. 2003;60:51-9.

54. Wyde PR, Moylett EH, Chetty SN, Jewell A, Bowlin TL, Piedra PA. Comparison of the inhibition of human metapneumovirus and respiratory syncytial virus by NMSO3 in tissue culture assays. Antiviral Res. 2004;63:51-9.

Received: 13 August 2009

Accepted: 13 January 2010 